\title{
Natural history of subclinical hypothyroidism in children and adolescents
}

\author{
Ewa Małecka-Tendera \\ From 4th Congress of the Polish Thyroid Association 2013 \\ Lodz, Poland. 11-13 April 2013
}

\begin{abstract}
Diagnosis of subclinical hypothyroidism $(\mathrm{SH})$ is based on interpretation of biochemical tests in the absence of the evident clinical symptoms. Mildly elevated TSH with nor$\mathrm{mal} \mathrm{fT}_{4}$ are common in adults and the prevalence of this finding is reported to be $1-10 \%$ of general population, being higher in the elderly. In pediatric population its prevalence is lower than $2 \%$. Moreover in about $60 \%$ of subjects the natural course of $\mathrm{SH}$ is a reversal of the elevated TSH to normal values. Only $3 \%$ of them progress to overt hypothyroidism with TSH values above $10 \mathrm{mUI} / \mathrm{l}$. The risk of progression is higher in patients with elevated anti-thyroid antibodies and higher degree of hypoechogenicity at thyroid ultrasound. Increased prevalence of $\mathrm{SH}$ is described in obese and overweight subjects, children with Down's syndrome, with diabetes type 1 and in girls with Turner's syndrome. Studies regarding the natural history of $\mathrm{SH}$ and its consequences in children are scarce and their conclusions are controversial. Meta-analysis of 39 potentially relevant articles showed that $\mathrm{SH}$ in children seems to be a remitting process with a low risk of progression toward overt hypothyroidism regardless of the $\mathrm{L}_{-} \mathrm{T}_{4}$ treatment. There was also no clear evidence of the beneficial effect of $\mathrm{L}-\mathrm{T}_{4}$ treatment on psychological and physical development. Replacement therapy did not seem to be justified in children with SH and TSH values between $5-10$ $\mathrm{mUI} / \mathrm{l}$, no goiter and negative anti-thyroid antibodies. Therefore decision regarding the treatment of the young patient with elevated TSH but normal $\mathrm{fT}_{4}$ value continues to be controversial.
\end{abstract}

Published: 5 April 2013

Department of Pediatrics, Pediatric Endocrinology and Diabetes, Medical University of Silesia, Katowice, Poland

C Biomed Central

(c) 2013 Małecka-Tendera; licensee BioMed Central Ltd. This is an Open Access article distributed under the terms of the Creative Commons Attribution License (http://creativecommons.org/licenses/by/2.0), which permits unrestricted use, distribution, and reproduction in any medium, provided the original work is properly cited.
doi:10.1186/1756-6614-6-S2-A41

Cite this article as: Małecka-Tendera: Natural history of subclinical hypothyroidism in children and adolescents. Thyroid Research 2013 6(Suppl 2):A41.

Submit your next manuscript to BioMed Central and take full advantage of:

- Convenient online submission

- Thorough peer review

- No space constraints or color figure charges

- Immediate publication on acceptance

- Inclusion in PubMed, CAS, Scopus and Google Scholar

- Research which is freely available for redistribution 